\title{
SMEs' Use Of Financial Statements For Decision Making: Evidence From Pakistan
}

\author{
Shamim Akhtar, Xidian University, China \\ Yanping Liu, Xidian University, China
}

\begin{abstract}
Financial statements comprise of insightful statistics about likely risk and the return associations of many decisions and have significant role in firms' success, particularly for SMEs. Thus, through a sample of 94 Pakistani small and medium enterprises (SMEs), this study inspects the influences that could have impact on firms' practice of the financial statements in making significant financial decisions. Principle component analysis finds key factors which define use of financial statements containing; experience, knowledge and ability. Logit analysis then discloses that these variables have significant association with whether Pakistani SME owners use financial statements while making business decisions. Findings indicates that the owners of Pakistani SMEs practice financial statements in decision making rendering to their knowledge about financial statements, experience and finally their ability to interpret figures confined in financial statements. Outcomes should be valuable for SME owners, educators, and the service providers.
\end{abstract}

Keywords: Financial Statements; Small Firm Financing; Small Firm Decisions

\section{INTRODUCTION}

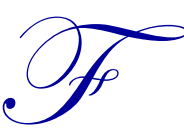

inancial statements contain all the necessary information required to make financial decisions either investing or lending. Effective decision making in SMEs necessitates the obtainability of financial information and then its deployment in decision making (Gibson, 1992). Financial statements benefit owners, managers and investors in many ways for instance, the stakeholders can make use of financial information to gain a better understanding about financial aspects, risk profile and investment avenues of their firm (Van Auken, 2013). Though the owners and stakeholders can make better decisions by utilizing financial statements, but small firm owners often are not well equipped in efficient use of financial statements. Therefore, even reliable and timely prepared financial statements are not enough, when owners do not have the ability to use and interpret them accurately (Vanauken, 2005). The utilization of financial statements is very much related to and helpful of any firm's planned goals, as if decisions made without considering their financial influence it can cause a jumbled company emphasis and monetary suffering (Horngren, Datar, Foster, Rajan, \& Ittner, 2009).

The significance of financial decisions is evident from the higher failure rate among small firms because of their weak financial management (van Praag, 2003). Owners of SMEs often do not have robust finance expertise and thus they may not completely comprehend the influence of their decisions on the firm. Financial literacy of owners for the growth of firms seems really crucial (Adomako, Danso, \& Damoah, 2015). Bad decisions threaten the firms sustainability and leaves the wide spread operational problems (Timmons \& Spinelli, 2004). As an alternative, firms should deploy financial statement facts to assess the effects of their decision (Breen, Sciulli, \& Calvert, 2004).) gain financial information and cope with their businesses well (Shields, 2010). The efficient use and effective interpretation of financial statements is necessary as leading cause of failure and financial distress is only the poor financial management of business (Coleman 2002; Carter \& Van Auken, 2005; Headd 2003; Wiklund \& Shepherd, 2005). In addition, owners may influence in a way while interpreting the financial statements by their perceptions about firm's financial situation and potential. Accurate and valid assessment is mandatory to achieve financial goals along with reliable and timely information. Entrepreneurs because of their optimistic thinking-perhapes overly so- about their business financial condition which can cause way out analysis, incorrect estimations, wrong assessment and probability of failure (Smith, 2011; Landier \& Thesmar, 2009). However, by external assistance, better and appropriate use of financial statements could help owners in developing right perceptions and accordingly more accurate and well 
informed decisions (Breen et al., 2004). Owners of SMEs incline not to seek out external financial assistance (Gooderham, Tobiassen, Doving, \& Nordhaug, 2004).

This study inspects elements connected with whether the owners of Pakistani SMEs use financial statements in making their business decisions. Usage of financial statements is important to a number of stakeholders because SMEs sustainability greatly depends on their financial health. However, only few studies addressed the usage of the financial statements (Shields \& Shelleman, 2011) although these statements comprised of very critical information to be used in all strategic and operational decision making; overlooking such information can cause manifold damages to firm (Carraher \& Vanauken, 2013; Vanauken, 2013). To address the intended issue, we analyze what elements influence the use of the financial statements by the owners of SMEs.

Thus, the investigation specifically exhibits how owners (Knowledge, experience and ability) relate to whether the owners of Pakistani SMEs make decisions on the basis of information revealed by the financial statements. This issue is critical that has not been analyzed in earlier literature, even though the SMEs have great contribution in the economic growth, employment generation and countries annual GDP. Prior literature focused only developed economies, so this study addresses this issue in a developing country thereby addresses another gap in previous literature. This study stems beyond academic contribution which defines how owner of the SMEs should use financial statements in decision making by analyzing how owners actually use them.

\section{SMEs in Pakistan}

SMEs segment is considered as back bone of the Pakistan economy. This sector plays vigorous role to boost up economy and the only survival in times of worse economic conditions. It is fair to say that Pakistan economy is the economy of SMEs. Approximately this sector constitutes $90 \%$ of all the business sectors, 77 percent of the total industrial employment is covered by this sector. Small and medium enterprises add 40\% in annual GDP of Pakistan (SMEDA Pakistan, 2010). SME sector in Pakistan also account for employment generation of about 21 million people and contribute 24 percent in the national manufacturing exports. The economic survey of Pakistan provides that almost 3.2 million SMEs are working in the country and add best in economy (SMEDA Pakistan, 2010).

Generally, it is acknowledged that SMEs have great contribution in developing the economy. Even though small and medium enterprises have significant role in the progress of the country still this sector overlooked in Pakistan and has not received sufficient attention from the researchers' side. Entrepreneurs face many problems which restrict the long term viability and development of firms. Pakistan is among one of those countries where the inflation rate is very high and the business industry is entirely under uncertainty. The failure rate of SMEs progress in developing countries is higher than in the developed ones (Arinaitwe et al. 2006). So, to develop a prosperous economy, the business sector particularly SMEs sector requires attention. As said by 1998 estimate, though SMEs sector consist of $85 \%$ of the business sector, yet most of SMEs face insufficiency of funds, less technological competencies, obsolete production amenities, traditional products and an unavailability of the qualified work force (Raouf, 1998). Khawaja (2006) reported that the regulatory policies in Pakistan are conducive in nature Government policies are focused mainly on the large firm's development. Clearly it is evident that there are many problems associated with the success of SMEs and owners need to be act more wisely.

\section{SMEs and Importance of Use of the Financial Statements}

Worthy decisions by small and medium enterprises greatly dependent on the access to correct, reliable, and consistent financial data which make available intuitions about the effects of different situations (Shields \& Shelleman, 2011). Business owners lacking in knowledge about the possible impact of the decisions made by them, may lead them to the risky choices and lessen the business inflows (Van Auken, 2001). The excellence of the preparation of the financial statements, also the relevance of subsequent evaluation both define usefulness of decisions by SME's (Carraher \& Van Auken, 2013).

Reliability of the financial statements and effectiveness of decision are mainly significant for SMEs for the reason of their partial admittance to the financial wealth. Weak decisions speedily can bring business to operational troubles, and incompetence to track market breaks (Vanauken, 2013). Worthy financial statistics are particularly essential, as 
entrepreneurs frequently depend on their partialities or heuristics in making decision (Mitchell et al. 2007), bringing to the decision inaccuracies which are unfavorable to the firm. On the other hand, as per Busenitz and Barney (1997) partialities and the heuristics can make simpler conditions and assist decisions in circumstances, where the owners lack in to comprehend needed information.

Firm owners therefore generally undergo knowledge gap, as they are not much alert of or well-informed about the financial effect of their decision. This gap particularly can be damaging to the small businesses that are not using the financial statements, for the reason that they lack financial data, inappropriate data, or improper practices of the data certainly lead to financial distress and failure. Inclusive, SMEs may pointlessly sustain business and the financial risks which are bigger than related gains (Vanauken, 2005). Brigham \& Ehrhardt (2013) argued that traditional finance theory assumes that the information, together with the financial statistics, is easily and broadly accessible, correctly and quickly transferred in an obvious way to the stakeholders.

Many studies put emphasis on SMEs that they need to get dependable, precise information for making accurate decisions (Van Auken 2013; Shields \& Shelleman, 2011). However, the information flow amongst SMEs inclines to be limited by some constrictions that rise from the weak quality of information, lack of inspiration, limited experience of owners, inadequate resources and the higher agency cost (Madrid, Garcia \&Van Auken, 2009). Large firms hence are more probable to tie suppositions of the theory of finance than are private, small SMEs.

Financial statements are the sources of influencing and extremely applicable information (Carraher \& Van Auken, 2013). The financial statements are comprised of significant information that make available exact data that needed to perform reliable analysis which is equally important for owners and other stakeholders. Their significance is especially manifest in relation to probable impacts of weak financial decisions, poor management of small firms and the higher rate of their failure (Van Praag, 2003). SME owners generally do not have strong skills and have poor understanding about preparing and interpreting the financial statements in the context of making important business decisions (Van Auken, 2005). Moreover, SMEs time and again make decision in the ambiguous environment, deprived of comprehensive information, which is an impractical ultimate for them (Beck \& Demirguc-Kunt, 2006).

\section{RESEARCH ISSUES}

Financial statements make available unbiased data regarding the present financial position of the firm and therefore can be castoff to evaluate the influence of present decision on the forthcoming processes (Carraher \& Van Auken, 2013). For instance, scenario analyses centered on correct financial data that can determine the risk acquaintance and the financial consequences linked with different decisions. SME owners who lack the independent financial information cannot limit the prospective effect of their decision on their business, thus they might sort out choices that superfluously generate hostile situations, greater risk, or the concentrated returns (Van Auken, 2005).

Van Auken (2013) and Halabi, Barrett \& Dyt (2010) emphasize that, small firms often remain financially deprived and inexperienced thus pay no attention to financial figures at times of decision making. Decision making involves numerous factors and is very complex in small firms (Romano, Tanweski \& Smyrnios, 2001; Romano \& Ratatunga, 1994). However, Busentiz and Barney (1997) argued that narrow experience and self-confidence generally leads to imperfect decisions. SMEs are mainly vulnerable towards the influence of poor and weak financial decisions as of their restricted admittance to the financial markets and limited alternate means of capital. The owners those have the knowledge and worth the financial data are expected to be use statements more contrary to those who do not have understanding of the statements (Carraher \& Van Auken, 2013).

Though the traditional finance theory emphasizes on making rational decision, the behavioral finance admits the likely impact of the overconfidence and the optimism (Barberis \& Thaler, 2002). Roberts \& Sian (2009) identify that small business owners generally do not comprehend or are jumbled by data reflected in the financial statements.

The supposed complication of financial statements can drive SMEs owner to depend on accountants to describe the statistics (Shields \& Shelleman, 2011). These actions point toward absence of financial expertise among business owners and consequently the necessity for financial statement preparation and trainings (Cassar \& Ittner, 2008). Experienced owners who have better capabilities and have larger self-reliance in their financial statements probably 
expected more to be use outside accountants to seek expert advice, as they apprehend the significance of correct statements (Sian \& Roberts, 2009; Van Auken, 2013). The capacity to deduce financial statements and consequently application of that information by the owners is important as these capabilities gives more confidence to the owners and thus they are more likely to use such valid information while decision making. This rational leads to the following hypotheses:

H1: Owners who have more business experience use financial statements in making decisions than those who do not have much experience.

H2: Owners who have greater ability to interpret the financial statements use financial statements in decision making than those who do not have such ability.

H3: Owners, who have better knowledge about financial statements, use financial statements in decision making than those who do not have much knowledge.

\section{METHODOLOGY}

\section{Study Settings}

To test the proposed hypothesis, we used sample of SMEs from Lahore (Pakistan). Lahore is the second most populous city of Pakistan with population of over 7 million. And the Lahore city is the main hub of industry including SMEs that's why this region becomes the main attraction for this study. As developing economy, Pakistan has confronted many problems related to SME sector yet, SME sector is considered as the main pillar of Pakistan's economy in relation of its input towards GDP, the employment generation and the export expansion. Illiteracy of the entrepreneurs generates the problem in gaining access to finance, managing finance related decisions which make it difficult to manage small firms in developing countries (Baah-Nuakoh, 2003). For this cause, less educated, inexperienced and incapable individuals likely to establish just survival oriented business. Thus, in developing countries the financial illiteracy can be one of the reasons that SME owners do not use financial statements in making significant decisions. Hence, we conduct our study in a setting where owner's knowledge about financial matters or financial illiteracy may be one of the key barriers in the success of SMEs.

\section{Sample and Data}

The questionnaire used in this study was constructed on study by Carraher \& Van Auken (2013) but also modified to reveal the particular problems related to Pakistan's operating system. Final Questionnaire stemmed from focus group discussions and the previous studies on SME finance decisions (Hornsby \& Naffiziger, 1997; Busenitz et al., 2003; Carter \& Van Auken, 2006). Questionnaire contained of two parts, in the first part respondents were asked about their firm features for instance, firm age, assets of the firm, type, structure, income and the gender of owner. The other section centered on the financial statements containing, their use in decision making, how frequently they prepare their financial statements over financial year, how confident they are about the accuracy of the statements and lastly their capability to comprehend the financial statements. The data collected from the Lahore chamber of commerce and industry (LCCI) in Lahore, Pakistan. Our sample is a representative of the members of city chamber of industry to represent the business community and to achieve the maximum results. Owners were contacted through networking and by the support of the chamber of commerce $100 \%$ response rate achieved. Thus, there were no non-respondents.

The regional specificity serves some added benefits to the study. First, it assisted data gathering-a benefit particularly related as the area differences that might be present among the owner of SMEs. Secondly, data from particular area lessens the number of extraneous variables. Let's say, different areas of country may possibly reflect different levels of provision for SMEs and also deviations in banking rehearses connected with the requirements of financial statements (Carter \& Van Auken 2006). The SME owners attended as the respondents due to their significance as the decision makers and for the reason that their awareness or insights shape the strategic behavior (Van Gils, 2005). Thus the 94 useable questionnaires received from the owners of Pakistani SMEs. 


\section{ANALYSIS}

To unify data into cliques with the common subjects linked with the usage of the financial statements in decision making; this study cast-off the principal components analysis with the Varimax rotation. Principal components analysis lessens the data set with a multiple extents into the set of constituents with alike association arrangements; Aimed at this study, variables used were likely to be allied with the owner's decision to have faith in the financial statements, such as acknowledged from literarutre (Busenitz et al., 2003; Carter \& Van Auken 2006; Cassar \& Ittner, 2008; Kuratko, Hornsby, \& Naffiziger, 1997; McMahon \& Stanger, 1995; Petty \& Bygrave, 1993; Van Auken, 2005). These variables also considered by the Carraher and Van Auken (2013), that is (a) owners age; (b) experience of owner in industry; (c) frequency of financial statement preparation (never, annually, quarterly, monthly); (d) confidence on the correctness of the statements; (e) owners confidence on own capability to interpret the statements ( $1=$ very confident; $7=$ not confident); (f) New business initiatives taken by the owner; (g) Average ranking of owner on the competitiveness of the following factors: expansion of products and services, launch of new product, exposing new markets, searching new suppliers, enhancement of present services and products, better customer linkage, developing business processes, and lessens cost of services/products sold ( $1=$ not important; $7=$ very important); (h) venue where owner gained the financial knowledge (self-taught, training sessions, on job trainings, formal education).

All the variables were gathered into relevant sets by the principle component analysis.

The factor coefficient value of .5 or larger recognized the allied variables for every factor.

Afterwards, the Spearman correlation analysis assisted to measure the correlations concerning the independent variables. Coefficient approximation is a non-parametric technique, centered on the ranks instead of the values of the responses, which was suitable for this research because of uncertainty related to the population dissemination. Logit regression model tested the relation between the use of the financial statements in decision making and the factors as of the principal component analysis. For the logit model the dependent variable was whether in decision making owners used financial statements $(1=$ yes, $0=$ No). The independent variables used in this study were the three factors obtained from principle component analysis. In entrepreneurship research regression analysis comes as communal technique for the reason that it deals with the most suitable method to comprehend the relationship among dependent and the independent variables. Particularly, related for studying how shifts in independent variable changes the dependent variable.

The regression model was:

$$
D M=\beta 0+\beta 1(\text { Education })+\beta 2(\text { Assets })+\beta 3(\text { Ability })+\beta 4(\text { Knowledge })+\beta 5(\text { Experience })+\varepsilon
$$

Where,

$\begin{array}{ll}\text { DM } & =\text { whether in decision making owners used financial statements } \\ \text { Education } & =\text { Level of owners education } \\ \text { Assets } & =\text { Business total assets } \\ \text { Ability } & =\text { Factor } 1 \\ \text { Knowledge } & =\text { Factor } 2 \\ \text { Experience } & =\text { Factor } 3 .\end{array}$

\section{RESULTS}

\section{Sample Characteristics}

Univariate statistics helped in revealing the characteristics of the responding firms as well as the respondents thus, we report their percentages by category first. Results disclose that below one- half of the respondents had the highest educational level of bachelor's degree and above half of them had just high school education. And most of them were male (93.6\%) around half of the firms were structured as the sole proprietorships, subsequently partnerships (32.2\%) 
and corporations (18.9\%). Majority of the firms operated in manufacturing (48.7\%) and from services sector (20.2\%). A big percentage of respondents had greater than $\$ 100,000$ total assets. Similarly, their total income was mostly higher than $\$ 100,000(53.6 \%)$, however nearly $30 \%$ of the firms had less than $\$ 50000$.

Table 1. Responding Firm's Features $(n=94)$

\begin{tabular}{|c|c|}
\hline Owner's Level of Education & $\%$ \\
\hline High School & 26.3 \\
\hline College Degree & 59.7 \\
\hline Master's Degree & 4.9 \\
\hline Others & 9.1 \\
\hline \multicolumn{2}{|l|}{ Gender of Owners } \\
\hline Male & 94.3 \\
\hline Female & 5.7 \\
\hline \multicolumn{2}{|l|}{ Legal Status of firm } \\
\hline Sole Proprietorship & 48.9 \\
\hline Partnership & 32.2 \\
\hline Other & 18.9 \\
\hline \multicolumn{2}{|l|}{ Business Type } \\
\hline Retail & 16.3 \\
\hline Service & 27.1 \\
\hline Manufacturing & 20.3 \\
\hline Agricultural & 25.1 \\
\hline Others & 11.2 \\
\hline \multicolumn{2}{|l|}{ Firms Total Assets } \\
\hline$<\$ 50,000$ & 14.3 \\
\hline$\$ 50,001-\$ 100.000$ & 18.7 \\
\hline$>\$ 100,000$ & 67.0 \\
\hline \multicolumn{2}{|l|}{ Firms Revenue } \\
\hline$<\$ 50,000$ & 31.5 \\
\hline$\$ 50,000-\$ 100,000$ & 16.8 \\
\hline$>\$ 100,000$ & 51.7 \\
\hline
\end{tabular}

In table 2 the mean values are reported that how frequently owners preferred to prepare financial statements $(1=$ monthly, 2 = quarterly, 3 = annually, $4=$ never), as that greater the mean, the more frequently they prepared the statements. The results specify a prevalence of the cash budgets and the balance sheets were primed least frequently. Furthermore, forecasts were formulated more often than of financial statements.

Table 2. Frequency Means of the Financial Statement Preparation ( $n=94)$

\begin{tabular}{l|c|c}
\hline \multicolumn{1}{c}{ Financial Statements } & Means & Standard Deviation (SD) \\
\hline Income Statement & 2.13 & 0.892 \\
\hline Balance Sheet & 2.27 & 0.931 \\
\hline Cash Budget & 1.48 & 1.012 \\
\hline Sales Forecasts & 1.89 & 1.031 \\
\hline Expense Forecasts & 1.97 & 1.102 \\
\hline
\end{tabular}

\section{t-test of the Difference in Means}

Analysis comprised of investigating the association between entrance to the external support and the financial statements frequency of preparation. Thus table 3 reported the t-test of differences among means that how frequently firms prepared their financial statements that accessed the external support verses the firms which did not. Firstly, most of the firms accessed the external assistance. Secondly, mean values showed that balance sheet and income statements were organized less frequently as compare to the sale forecast, cash budget and the expense forecasts. Third, those firms which accessed the external assistance they prepared totally their statements more frequently than 
the firms those did not get external assistance. Pakistani SME owners thus looked to know the worth of the external assistance; those who get external support also prepared their financial statements frequently than others that did not get.

Table 3. t-test of the Mean responses: the statements used to make decisions with relation to external assistance

\begin{tabular}{|c|c|c|c|c|c|}
\hline Financial Statements & Mean & Assistance/Support & $\mathbf{n}$ & Mean & t-Statistics \\
\hline \multirow{2}{*}{ Income Statement } & \multirow{2}{*}{2.37} & No external support & 40 & 2.17 & $0.000^{*}$ \\
\hline & & External support & 43 & 1.67 & \\
\hline \multirow{2}{*}{ Balance Sheet } & \multirow{2}{*}{2.43} & No external support & 37 & 2.19 & $0.000^{*}$ \\
\hline & & External support & 36 & 2.15 & \\
\hline \multirow{2}{*}{ Cash Budget } & \multirow{2}{*}{1.28} & No external support & 37 & 1.59 & $0.042^{* *}$ \\
\hline & & External support & 39 & 1.43 & \\
\hline \multirow{2}{*}{ Sales Forecast } & \multirow{2}{*}{1.89} & No external support & 40 & 2.17 & $0.038^{* *}$ \\
\hline & & External support & 42 & 1.92 & \\
\hline \multirow{2}{*}{ Expense Forecast } & \multirow{2}{*}{1.87} & No external support & 45 & 1.99 & $0.026^{*}$ \\
\hline & & External support & 41 & 2.13 & \\
\hline
\end{tabular}

* Significant level at $1 \%$

** Significance level at 5\%

\section{Principle Component Analysis}

Three factors obtained from the component analysis (Table 4). The variables involved in the Factor 1 were the accuracy and the ability of owners to interpret the statements therefore, this factor labeled as (ability). Experience and age variables established the factor 2 as (Experience). Financial knowledge and the preparation variables constituted factor 3 and it was labeled as (Knowledge).

Table 4. Principle component analysis via the varimax procedure $(n=94)$

\begin{tabular}{|c|c|c|c|}
\hline Variables & F 1(Experience) & F 2(Ability) & F3(Knowledge) \\
\hline Age & 0.0493 & 0.876 & 0.062 \\
\hline Frequency & -0.395 & 0.325 & 0.725 \\
\hline Experience & 0.051 & 0.899 & 0.137 \\
\hline Reliability & 0.718 & 0.410 & 0.332 \\
\hline Ability to interpret & 0.892 & 0.013 & 0.269 \\
\hline New business started & 0.421 & -0.131 & -0.136 \\
\hline Competition & 0.791 & 0.038 & 0.108 \\
\hline Knowledge & 0.210 & 0.131 & 0.921 \\
\hline Factor & Eigenvalue & Differences & Proportions \\
\hline 1 & 2.873 & .829 & .281 \\
\hline 2 & 2.147 & .865 & .217 \\
\hline 3 & 1.329 & .310 & .210 \\
\hline
\end{tabular}

\section{Correlations}

Table 5 contained the correlations between independent variable factors, indicating the low correlations between independent variables (ability, knowledge, experience, total assets, and education). Low correlations propose that there should not be a problem of multicollinearity. 
Table 5. Spearman Correlations among variables $n=94$

\begin{tabular}{l|c|c|c|c|c}
\hline \multicolumn{1}{c|}{ Variable } & Education & T. Assets & Factor 1 & Factor 2 & Factor 3 \\
\hline Education & 1.0 & & & & \\
\hline T. Assets & .420 & 1.0 & 1.0 & & \\
\hline Factor 1 & 0.279 & .612 & .035 & 1.0 & 1.0 \\
\hline Factor 2 & -.314 & 0.120 & -.318 & -.091 & \\
\hline Factor 3 & -.130 & -0.021 & & & \\
\hline
\end{tabular}

\section{Logit Regression Analysis}

Regression outcomes $\left(\mathrm{x}^{2}=22.939\right.$, at $1 \%$ significance level $)$ show the relationship of, the owners use of statements in decision making (a) with the set of control variables i.e. total assets and education (b) experience, ability, knowledge the independent variables. Coefficient of experience variable (-0.125, at $5 \%$ significance level) is directly associated with whether the firm owners use financial statements in decision making, supported H1. Hence the owners of Pakistani SME who make decisions by using their financial statements are more experienced as compare to those who do not bother financial statements while making decisions. On the other hand, the owners who do not use statements in making decisions are less experienced as compare to those who utilize the financial statements. The second variable "ability" coefficient value (0.091) also positively associated with the usage of financials while decision making, in support of H2. Revealing that the owners of firm who make decisions with the use of financial statements have greater ability and confidence in their statements contrary to those who have low confidence in their ability to interpret and accuracy of the financial statements.

Table 6. Logit Regression Analysis

\begin{tabular}{l|c}
\hline \multicolumn{1}{c}{\begin{tabular}{l} 
Use of financial statements in decision making=Dependent variable n=94 \\
\multicolumn{1}{c}{ Variable }
\end{tabular}} & Coefficient \\
\hline Intercept & -5.104 \\
\hline Education & 0.062 \\
\hline T. Assets & $0.813^{*}$ \\
\hline Experience & $0.125^{* *}$ \\
\hline Ability & $0.091^{* *}$ \\
\hline Knowledge & $0.041^{* *}$ \\
\hline Notes: $\chi^{2}=22.939 * * *$ \\
$*$ Significant at $10 \%$ & \\
$* *$ significant at $5 \%$ & \\
$* * *$ significant at $1 \%$ &
\end{tabular}

The coefficient for knowledge variable ( 0.041 significant at $5 \%$ ) shows the direct relationship whether statements inform decisions, in support of $\mathrm{H} 3$. This association suggests that firm owners with higher knowledge more likely to use financial statements in decision making contrary to those who have less knowledge or financial literacy.

Results also show that education variable is not suggestively associated with the financial statement use while decision making. Finally, the coefficient for total assets $(0.813$ significant at $10 \%)$ reveals the weak association with the financial statements use by the owner while they make decisions. Thus, the firms with larger amount of assets may perhaps have greater inclination towards the use of financial statements in making decisions than those firms who have fewer assets.

\section{DISCUSSION}

Understanding that how owners react to the significant information enclosed in the financial statements is particularly important for their role in making decision (Carraher \& Van Auken, 2013). Among the important sources of information about the business health, the financial statements are considered at the top priority thus, while decision making the effective use and accurate interpretation of financial statements leads to the viability of any business especially for SMEs. Ineffective decisions on the other hand always associated with the weak or poor financial management, prime cause of business distress and failure (Headd, 2003). Efficient owners can chase best business 
prospects by dealing with the significant information from financial statements. Worthy financial decisions are grounded on consistent, dependable financial information and on the ability to comprehend the financial statements. Firms' operational and financial goals can only be achieved by the effective decision making and efficient financial management (Vanauken, Ascigil \& Carraher, (2016). Along with trustworthy figures the ability to comprehend and accurate interpretation of financial statements is the pre-requisite for efficient decisions (Carraher \& Van Auken, 2013).

The results of this study offer greater understanding into the small firm owners 'usage of financial statements. Mainly three factors are focused in this study, obtained through the principle component analysis, which mirror those variables that likely have fundamental effects on financial statements use (Timmons \& Spinelli, 2004; McMahon, 2001). Findings of the study show a positive relationship of factors (experience, ability, knowledge) with the owners' financial statements based decisions. A great degree of constancy confirms the construal of these relationships. Intended for all relationships, the owner who uses financial statements in decisions have more ability to understand and interpret financial statements, are more experienced and they also have more knowledge of significant financial statements.

Thus altogether, these associations suggest the importance of financial statements and their use in decision making by the owners who have better understanding about financial matters, they make effective use of financial data to make good decisions. Skill to gain and interpret exact financial information is particularly significant for small firms, where weak financial management and poor decision making is the primary root of failure (Carter \& Van Auken, 2006).

Owners, who have more experience, understand the importance of financial statements and use them while making decisions (Sheilds, 2010). Thus, the relationship among experience of owners and their use of financial statements, cited as significant. Owners with more experience know that important decisions particularly those that are of higher expenditure, can bring extensive financial consequences. Integration of financial statements in decision making process assists owners to calculate the risk effects and financial outcomes of their decisions (Berger \& Udell, 1998). Experienced owners with understanding of the significance of financials can better examine the influence of their decisions on profits, liquidity and the risk (Shields, 2010).

The indirect relation among owner's insufficient knowledge about financial statements and their use in decision making highlights that owners with higher knowledge with respect to the facts enclosed in the financial statements are most likely to use these financial statements. On the contrary, insufficient knowledge about the financial statements makes their use less often in decision making process. Small firm owners who possess less knowledge needed to know the worthy financial statements information may remain incapable to interpret those financial statements and to integrate them in process of decision making (Carraher \& Van Auken, 2013).

The findings also show that owners those have greater ability to interpret financial figures are most likely to use them in their decisions. On the other side the inability of small firm owners to interpret exact information lead them feel less confident and they do not use that valuable information while making business decisions. The use and accuracy of financial statements can be influenced by the owner's perceptions about their firm's potential. For instance, entrepreneurs tend to be optimistic about their businesses' that may lead to wrong calculation of the risk of failure, infectivity of decisions and financial distress of firm (Smith, 2011; Landier \& Thesmar, 2009). Thus, instead of making forecasts they should depend more on the financial statements while making significant decisions about their businesses, as they apprehend their importance and rely on their worth. This sequence also counterparts the behavioral finance theory, where decision makers make opinions that affect their practices (Ritter, 2003; Barberies \& Thaler, 2002).

Struggles to increase the quality of Pakistani SMEs' financial knowledge and reporting may possibly be leveraged to enhance the use of financial statements in decision making. Training programs could also help owners, accountants and decision makers to understand the worth of financial statements which will be crucial for the continual internalization of Pakistan economy, particularly as it increases greater access towards the capital markets. Obstacles to capital attainment and competitiveness also could be condensed by the effective use of financial statements (Ibicioglu, Dalgar \& Kocabiyik, 2010). 


\section{CONCLUSION}

This analysis of the factors linked with whether Owners of SMEs use financial statements is grounded on sample of 94 SMEs positioned in Lahore, Pakistan. Literature reveals that very few studies have looked at the role of financial statements while making decisions by the SMEs, particularly out of the United States. The findings of this research therefore contribute towards the literature stream by offering greater intuitions into the dire part of financial statements in decisions; various decisions solely depend on the information of financial statements and carries significant impact on all the stakeholders of the firm.

In particular, Pakistani SMEs owner who make use of financial statements in decision making have better ability to deduce the financial data in the statements, have more experience contrary to those who do not use financial statements and have significant knowledge about the financial statements. These outcomes are in support of all the proposed hypothesis of this study. Seeing the growing prevalence and the position of SMEs in the economy of Pakistan, research that offers understandings into means to recover their enactment have considerable positive prospective. For instance, the upshots of this study should prove beneficial for the owners of Pakistani SMEs, business educators and service providers to SMEs. The significance of using financial statements in decisions is obvious; better practice of the figures confined in the financial statements possibly could direct more operational and worthy decisions. Therefore, financial statements should be utilized by the outside evaluators and inside firm, to guide better decisions. Service suppliers should assist SME owners to apprehend the significance of financial statements in their decisions. Moreover, educators should give emphasis to that financial statistics can lessen uncertainty and deliver intuitions into how the subsequent decisions define firms' financial strength. An improved appreciative about the impact of these elements should develop the manner by which SMEs owner integrate the data of financial statements in the decisions.

Finally, some limitations of this study advise avenues for the further research. The research could be extended to deal a broader outlook on how small and medium enterprises from place to place in the world practice financial statements, as well as see the sights in different regions. This research did not test the correlation among financial statement use and of the firm's cost-effectiveness thus, further studies can pursue this slot. Moreover, the findings are centered on a rather small sample and the data collected at a single point in time. Finally, a longitudinal study with a relatively larger sample might deliver added suggestion regarding how firms practice financial statements at changed periods of their growth or through business cycle.

\section{AUTHOR BIOGRAPHIES}

Shamim Akhtar is currently doing her Ph.D. in Finance from School of Economics and Management, Xidian University, Xi'an, Shaanxi, PR China. She has teaching experience at University level.

Yanping Liu is a professor of finance in School of Economic and Management, Chief Financial Officer, Xidian University, Xi'an, Shaanxi, PR China. He has extensive teaching and research experience at a University level.

\section{REFERENCES}

Adomako, S., Danso, A., \& Damoah, J. O. (2015). The moderating influence of financial literacy on the relationship between access to finance and firm growth in Ghana,Venture Capital. An International Journal of Entreprenurial Finance, $18(1), 43-61$.

Arinaitwe, J. K., (2006). Factors constraining the growth and survival of small scale businesses. A developing countries analysis. Journal of American Academy of Business, Cambridge, 8(2), 167-178.

Baah-Nuakoh, A. (2003). Environment, informal sector and factor markets: Studies on the Ghanaian economy. Vol. 2. Accra: Woeli.

Barberis, N. \& Thaler, R. H. (September 2002). A survey of behavioral finance. NBER Working Paper No. w9222. Available at SSRN: https://ssrn.com/abstract=332266

Barberis, N., Thaler, \& R. (2002). A Survey of behavioral finance. Working Paper \#922, National Bureau of Economic Research, Cambridge, MA.

Beck, T., \& Demriguc-Kunt, A. (2006). Small and medium-size enterprises: Access to finance as a growth constraint. Journal of Banking and Finance, 30(11), 2931-2943. 
Berger, A., \& Udell, G. (1998). The economics of small business finance: The roles of private equity and debt markets in the financial growth cycle. Journal of Banking and Finance, 22(6), 613-673.

Breen, J., Sciulli, N., \& Calvert, C. (2004). The role of the external accountant in small firms. Small Enterprise Research, 12(1), 5-14.

Brigham, E. \& Ehrhardt, M. (2013). Financial Management: Theory \& Practice, 14th ed., South Western Publishing, Mason, Ohio.

Busenitz, L. \& Barney, J. (1997). Differences between entrepreneurs and managers in large organizations: Biases and heuristics in strategic decision-making. Journal of Business Venturing, 12(1), 9-30.

Busenitz, L., West, P., Shepherd, D., Nelson, T., Zacharakis, A. \& Chandler, G. (2003). Entrepreneurship in emergence: Past trends and future directions. Journal of Management, 29(3), 285-308.

Busenitz, L., West, P., Shepherd, D., Nelson, T., Zacharakis, A., \& Chandler, G. (2003). Entrepreneurship in emergence: Past trends and future directions. Journal of Management, 29(3), 285-308.

Carraher, S. \& Van Auken, H. (2013). The use of financial statements for decision making by small firms. Journal of Small Business \& Entrepreneurship, 26(3), 323-336, DOI:10.1080/08276331.2013.803676

Carraher, S., \& Van Auken, H. (2013). The use of financial statements for decision-making by small firms. Journal of Small Business and Entrepreneurship, 26(3), 323-336.

Carter, R., \& Van Auken, H. (2005). Bootstrap financing and owners' perception of their business constraints and opportunities. Entrepreneurship and Regional Development, 17(2), 129-144.

Carter, R., \& Van Auken, H. (2006). Small Firm Bankruptcy. Journal of Small Business Management, 44(4), 493-512.

Cassar, G. (2009). Financial statement and projection preparation in start-up ventures. Accounting Review, 84(1), $27-51$.

Cassar, G. \& Ittner, C. (2008). Initial retention of external accountants in startup ventures. Available at http://ssrn.com/abstract $=1320697$.

Coleman, S. (2002). Characteristics and borrowing behavior of small, women-owned firms: Evidence from the 1998 Survey of Small Business Finances. Journal of Business and Entrepreneurship ,14(2), 151-166.

Demirguc-Kunt \& Beck (2006). Small and medium size enterprises: Access to finance as a growth constraint. Journal of Banking and Finance, 30(11), 2931-2943.

Gibson, B. (1992) Financial information for decision making: An alternative small firm perspective. Journal of Small Business Finance, 1(3), 221-232.

Gibson, B. (1992). Financial Information for decision making: An alternative small firm perspective. Journal of Small Business Finance, 1(3), 221-232.

Gooderham, P. N., Tobiassen, A., Doving, E. \& Nordhaug, O. (2004). Accountants and sources of business advice for small firms. International Small Business Journal, 22(1), 5-22.

Halabi, A., Barrett, R., \& Dyt, R. (2010). Understanding financial information used to assess small firm performance: An Australian qualitative study. Qualitative Research in Accounting \& Management, 7(2), 163-179. DOI: $10.1108 / 11766091011050840$

Headd, B. (2003). Redefining business success: Distinguishing between closure and failure. Small Business Economics, 21(1), 51-61.

Horngren, C., Datar, S., Foster, G., Rajan, M., \& Ittner, C. (2009). Cost accounting: A managerial emphasis, 13th ed. Upper Saddle River, NJ: Pearson Prentice Hall.

Ibicioglu, H., Kocabıyık, T., \& Dalgar, H. (2010). Financial statement utilization during decision making in SMEs: A comparative study among Turkish and European Managers. Marmara University, IIBF Journal, 28(1), 209-226.

Khawaja, S., (2006). SMEDA (CEO). Unleashing the growth potential of SMEs in Pakistan through productivity enhancement. SMEDA.

Kuratko, D., Hornsby, J., \& Naffiziger, D. (1997). An examination of owner's goals in sustaining entrepreneurship. Journal of Small Business Management, 35(1), 24-33.

Landier, A. \& Thesmar, D. (2009). Financial contracting with optimistic entrepreneurs. Review of Financial Studies, 22(1), 117150 .

Madrid, A., Garcia, D., \& Van Auken, H. (2009). Barriers to innovation among Spanish manufacturing SMEs. Journal of Small Business Management, 47(4), 465-488.

McMahon, R. (2001). Business growth and performance and the financial reporting practices of Australian manufacturing SMEs. Journal of Small Business Management, 139(2), 152-164.

McMahon, R. \& Stanger, A. (1995). Understanding the small enterprise financial objective function. Entrepreneurship: Theory and Practice, 19(4), 21-40.

Mitchell, R., Busenitz, L. B., Bird, C., Gaglio, J., McMullen, J., Morse, E., \& J. Smith (2007). The central question in entrepreneurial cognition research. Entrepreneurship Theory and Practice, 31(1), 1-27.

Petty, J. \& Bygrave, W. (1993). What does finance have to say to the entrepreneur? Journal of Small Business Finance, 2(2), 125-137.

Raouf, A., (1998). Development of operations management in Pakistan. International Journal of Operations and Production Management, 18(7), 649-650.

Ritter, J. (2003). Behavioral finance. Pacific-Basin Finance Journal, 11(4), 429-437. 
Romano, C. \& Ratatunga, J. (1994). Growth stages of small manufacturing firms: The relationship with planning and control. British Accounting Review, 26(2), 173-195.

Romano, C., Tanweski, G., \& Smyrnios, K. (2001). Capital structure decision making: A model for family business. Journal of Business Venturing, 16(3), 285-310.

Shields, J. (2010). Paper presented at the Small Business Institute Annual Conference, St Petersburg, Florida: Small business use of management accounting reports.

Shields, J. \& Shelleman, J. (2011). Management accounting reports in small businesses: Frequency of use and influence of owner locus of control and goals. Small Business Institute Journal, 7(1), 29-51.

Sian, S. \& Roberts, C. (2009). UK small owner-managed businesses: Accounting and financial reporting needs. Journal of Small Business and Enterprise Development, 16(2), 289-305.

SMEDA Pakistan, (2010). Retrieved from http://www.smeda.org.pk/main (Aug 20, 2010) SMEDA, Developing SME Policy in Pakistan.

Smith, S. (2011). Beg, borrow, and deal? Entrepreneurs' choice of financing and new firm innovation. Available at http://ssrn.com/abstract=1573685

Timmons, J., \& Spinelli, S. (2004). New Venture Creation, 6th ed. Chicago: Irwin.

Timmons, J., \& Spinelli, S. (2009). New Venture Creation, 6th ed. Chicago: Irwin.

Van Auken, H. (2001). Financing small technology-based companies: The relationship between understanding of capital and ability to price and negotiate investment. Journal of Small Business Management, 30(3), 240-258.

Van Auken, H. (2005). A model of small firm capital acquisition decisions. International Entrepreneurship and Management Journal, 1(3), 335-352.

Van Auken, H. (2013). Influences on frequency of preparation of financial statements among SMEs. International Journal on Multidisciplinary Approaches on Innovation, 1(1), 143-157.

Van Auken, H., (2000). The familiarity of small technology-based business owners with sources of capital: Impact of location and capitalization. Journal of Small Business Strategy, 99, 33-47.

Van Auken, H., Aşcigil, S., \& Carraher, S. (2014). Paper presented at Cambridge Business and Economics Conference, Cambridge, United Kingdom, July, 2014: The use of financial statements by Turkish SMEs.

Van Gils, A. (2005). Management and governance in Dutch SMEs. European Management Journal, 23(5), 583-589.

van Praag, C. (2003). Business survival and success of young small business owners, Small Business Economics, 21(1), 1-17.

Vanauken, H. E., Ascigil, S., \& Carraher, S. (2016). Turkish SMEs' use of financial statements for decision making. The Journal of Entrepreneurial Finance, 19(1).

Wiklund, J. \& Shepherd, D. (2005). Entrepreneurial orientation and small business performance: A configurational approach. Journal of Business Venturing, 20(1), 71-91. 